\title{
Evidence for the endothelin system as an emerging therapeutic target for the treatment of chronic pain
}

This article was published in the following Dove Press journal:

Journal of Pain Research

30 August 2014

Number of times this article has been viewed

\author{
Terika P Smith' \\ Tami Haymond' \\ Sherika N Smith' \\ Sarah M Sweitzer ${ }^{1,2}$ \\ 'Department of Pharmacology, \\ Physiology and Neuroscience, \\ University of South Carolina, \\ Columbia, SC, USA; ${ }^{2}$ Department \\ of Pharmaceutical and Administrative \\ Sciences, Presbyterian College School \\ of Pharmacy, Clinton, SC, USA
}

Correspondence: Terika Smith University of South Carolina School of Medicine, 6439 Garners Ferry Road, Columbia, SC 29209, USA

$\mathrm{Tel}+\mathrm{I} 8032163526$

Fax +l 8032163538

Email terika.smith@uscmed.sc.edu

\begin{abstract}
Many people worldwide suffer from pain and a portion of these sufferers are diagnosed with a chronic pain condition. The management of chronic pain continues to be a challenge, and despite taking prescribed medication for pain, patients continue to have pain of moderate severity. Current pain therapies are often inadequate, with side effects that limit medication adherence. There is a need to identify novel therapeutic targets for the management of chronic pain. One potential candidate for the treatment of chronic pain is therapies aimed at modulating the vasoactive peptide endothelin-1. In addition to vasoactive properties, endothelin-1 has been implicated in pain transmission in both humans and animal models of nociception. Endothelin-1 directly activates nociceptors and potentiates the effect of other algogens, including capsaicin, formalin, and arachidonic acid. In addition, endothelin-1 has been shown to be involved in inflammatory pain, cancer pain, neuropathic pain, diabetic neuropathy, and pain associated with sickle cell disease. Therefore, endothelin-1 may prove a novel therapeutic target for the relief of many types of chronic pain.
\end{abstract}

Keywords: endothelin-1, acute pain, chronic pain, endothelin receptor antagonists

\section{Discovery of endothelin-I as an algogen}

Endothelin-1 (ET-1) was discovered by its vasoconstrictive effects on pig arteries. ${ }^{1,2}$ It was thereafter isolated, cloned, and extensively studied as a new endogenous vasoactive peptide. Since then, the endothelin family has been implicated in several human pathological conditions, including congestive heart failure, ${ }^{3}$ hypertension, sepsis, asthma, renal failure, cerebral vasospasm, and neoplasia. ${ }^{4}$ Of great surprise, experimental administration of ET-1 in a human volunteer produced severe and long-lasting pain. ${ }^{5}$ This discovery created a paradigm shift in the investigation of ET-1 as not solely a vasoactive peptide, but potentially as an endogenous algogen important in the modulation of pain. Many pathological conditions in which pain is a major symptom show an elevation in plasma ET-1. This includes painful vaso-occlusive crisis and acute chest syndrome associated with sickle cell disease, Raynaud's disease, prostate cancer, ${ }^{6}$ breast cancer, and complex regional pain syndrome. Thus, there is growing interest in the endothelin family and its receptors as novel therapeutic targets for the treatment of pain.

\section{Cellular and molecular biology of endothelin- I}

ET-1 was named after the cells that were first known to produce it: endothelial cells. It is now recognized that ET-1 is produced by a variety of other cells including vascular smooth muscle cells, ${ }^{7}$ leukocytes, cardiac myocytes, ${ }^{8,9}$ mesangial cells, ${ }^{10}$ neurons, ${ }^{11}$ 
mast cells, ${ }^{12}$ and macrophages. ${ }^{13}$ ET-1 belongs to a family of closely related peptides that include endothelin-2 (ET-2), endothelin-3 (ET-3), endothelin-4 (ET-4), and the sarafotoxins. These are all similar in structure to ET-1 but are separate gene products with tissue-specific expression. ${ }^{3,4}$

Synthesis and release of ET-1 is modulated by both physiological and pathophysiological factors. Factors that have been shown to inhibit the production of ET-1 include nitric oxide, prostacyclin, and atrial natriuretic hormone. ${ }^{14}$ Factors that can induce the production of ET-1 include proinflammatory cytokines, growth factors, angiotensin II, norepinephrine, vasopressin, bradykinin, thrombin, mechanical stress, peripheral tissue injury, and hypoxia. ${ }^{15-17}$ In the vascular system, ET-1 is released from endothelial cells in a polarized fashion toward the smooth muscle interface. ${ }^{18}$ The elevation of plasma ET-1 levels following vascular injury is likely the result of spill-over from the smooth muscle compartment. ET-1 is thus acting as a local modulator of vascular tone, and not as a circulating hormone. ET-1 has a half-life of 7 minutes $^{19}$ and is cleared from plasma after degradation by endopeptidases..$^{20,21}$

The endothelin family signals through the seven transmembrane $\mathrm{G}$ protein-coupled endothelin $\mathrm{A}\left(\mathrm{ET}_{\mathrm{A}}\right)$ receptor ${ }^{22}$ and the $\mathrm{ET}_{\mathrm{B}}$ receptor. ${ }^{2,23,24}$ The two receptors can be differentiated by agonists and antagonists and in their cellular distributions (Table 1). ${ }^{23}$ The $\mathrm{ET}_{\mathrm{A}}$ receptor binds ET-1 with the greatest affinity, ${ }^{25}$ whereas ET-1, ET-2, and ET-3 all have equal affinity for the $\mathrm{ET}_{\mathrm{B}}$ receptor. ${ }^{26}$ The $\mathrm{ET}_{\mathrm{B}}$ receptor has further significance in ET-1 tissue clearance via agonist-dependent receptor internalization and lysosomal degradation. ${ }^{20,21}$

The $\mathrm{ET}_{\mathrm{A}}$ receptor couples to $\mathrm{G}_{\mathrm{q} / 11}$ and $\mathrm{G}_{\mathrm{q} 12 / 13}$ proteins, whereas the $\mathrm{ET}_{\mathrm{B}}$ receptor couples to $\mathrm{G}_{\mathrm{i} / \mathrm{o}}$ and $\mathrm{G}_{\mathrm{q} / 11}$ proteins. ${ }^{27}$ Both receptors mediate their actions through phospholipase $\mathrm{C}$ activation, which in turn activates inositol triphosphate and

Table I ET receptor agonists and antagonists commonly used in basic research and clinical studies

\begin{tabular}{lll}
\hline Receptor & Agonists & Antagonists \\
\hline $\mathrm{ET}_{\mathrm{A}}$ receptor & ET-I & BQ-I23, atrasentan, SB23455I, \\
& & $\begin{array}{l}\text { ABT-627, FRI393 I7, } \\
\text { A-I27722.5, YM598 }\end{array}$ \\
$E_{\mathrm{B}}$ receptor & ET-I, ET-2, ET-3, & BQ-788, A-19262I \\
& IRL-I620, & \\
& sarafotoxin S6C & \\
$\mathrm{ET}_{\mathrm{A}} / \mathrm{ET}_{\mathrm{B}}$ receptors & ET-I, ET-2, ET-3 & Bosentan
\end{tabular}

Notes: ET-I is listed as the only available agonist for the $\mathrm{ET}_{\mathrm{A}}$ receptor. ET-2 and ET-3 will bind to the $\mathrm{ET}_{\mathrm{A}}$ receptor, but they are not listed as $\mathrm{ET}_{\mathrm{A}}$ agonists, as they have a 100 -fold greater binding affinity for the $\mathrm{ET}_{B}$ receptor. ${ }^{26} \mathrm{ET}-\mathrm{I}$, ET-2, and $E T-3$ all have equal affinity for the $\mathrm{ET}_{\mathrm{B}}$ receptor. IRL-I 620 and sarafotoxin S6c bind exclusively to $\mathrm{ET}_{\mathrm{B}}$ receptors. Several antagonists are listed for both receptors that are known to bind selectively to the receptor listed. Bosentan is the only known antagonist that has equal affinity for both the $\mathrm{ET}_{\mathrm{A}}$ and $\mathrm{ET}_{\mathrm{B}}$ receptors. Abbreviation: ET, endothelin-I. diacylglycerol, causing a mobilization of calcium ${ }^{28}$ and activation of protein kinase C (PKC), ${ }^{4,29}$ as well as PKCindependent signaling pathways. ${ }^{4}$

\section{Clinical significance ET-I in the pain pathway}

ET-1 and its receptors are found throughout the pain signaling pathway (Figure 1). In the periphery, $\mathrm{ET}_{\mathrm{B}}$ receptors are expressed on endothelial cells, ${ }^{30}$ smooth muscle cells, ${ }^{31}$ macrophages, ${ }^{32}$ and keratinocytes within the dermis and epidermis of the skin, where the peripheral endings of nociceptors are located. In contrast, $\mathrm{ET}_{\mathrm{A}}$ receptors are expressed on the peripheral endings of the nociceptor themselves, as well as on nerve axons and the nociceptor cell bodies located in the dorsal root ganglion (DRG). ${ }^{33} \mathrm{ET}_{\mathrm{A}}$ receptors have been found on small, medium, and largesized nociceptors. ${ }^{34}$ In contrast, in the DRG, $\mathrm{ET}_{\mathrm{B}}$ receptors are found exclusively on satellite glial cells and Schwann cells that myelinate nociceptors, but not on the nociceptors themselves. ${ }^{33-35} \mathrm{ET}_{\mathrm{A}}$ and $\mathrm{ET}_{\mathrm{B}}$ receptors are expressed in the DRG in a ratio of $60: 40$, respectively. ${ }^{36}$

In humans, both small and large nociceptors also express endogenous ET-1 mRNA. ${ }^{37}$ Brief exposure of nociceptors to ET-1 enhances action potential generation, possibly through decreasing delayed rectifier-type $\mathrm{K}^{+}$currents. ${ }^{38}$ In addition, ET-1 evokes hyperpolarizing shifts in tetrodotoxin-resistant sodium channels on nociceptors. ${ }^{28,39}$ Alteration in these specific channels is known to be involved in pain transmission caused by other algogens. ${ }^{40}$ The shifts in the tetrodotoxinresistant sodium currents may be enough to cause depolarization of sensory fibers and reduce the threshold for activation (hyperalgesia) of those fibers. ${ }^{36}$

ET-1 mRNA is also found in laminae IV-VI in the spinal cord $^{37}$ and in a variety of brain regions associated with pain signaling, including the hippocampus, striatum, amygdala, hypothalamus, raphe nucleus, locus coeruleus, cerebral cortex, pontine tegmentum, and lateral reticular formation. ${ }^{41,42}$ Similarly, ET-1 protein is found extensively in laminae I-V, ${ }^{43}$ and $\mathrm{ET}_{\mathrm{A}}$ receptors have been found in the hypothalamus, reticular formation, pontine tegmentum, locus coeruleus, and substantia nigra. ${ }^{44,45}$ Thus, the endothelin system is located across multiple levels of the pain neuroaxis and participates in signaling cascades, the final effectors of which are key players in the physiology of acute pain.

\section{ET- $I$ in acute pain}

Peripheral administration of ET-1 produces pain and hyperalgesia in humans as well as paw flinching, licking, mechanical 


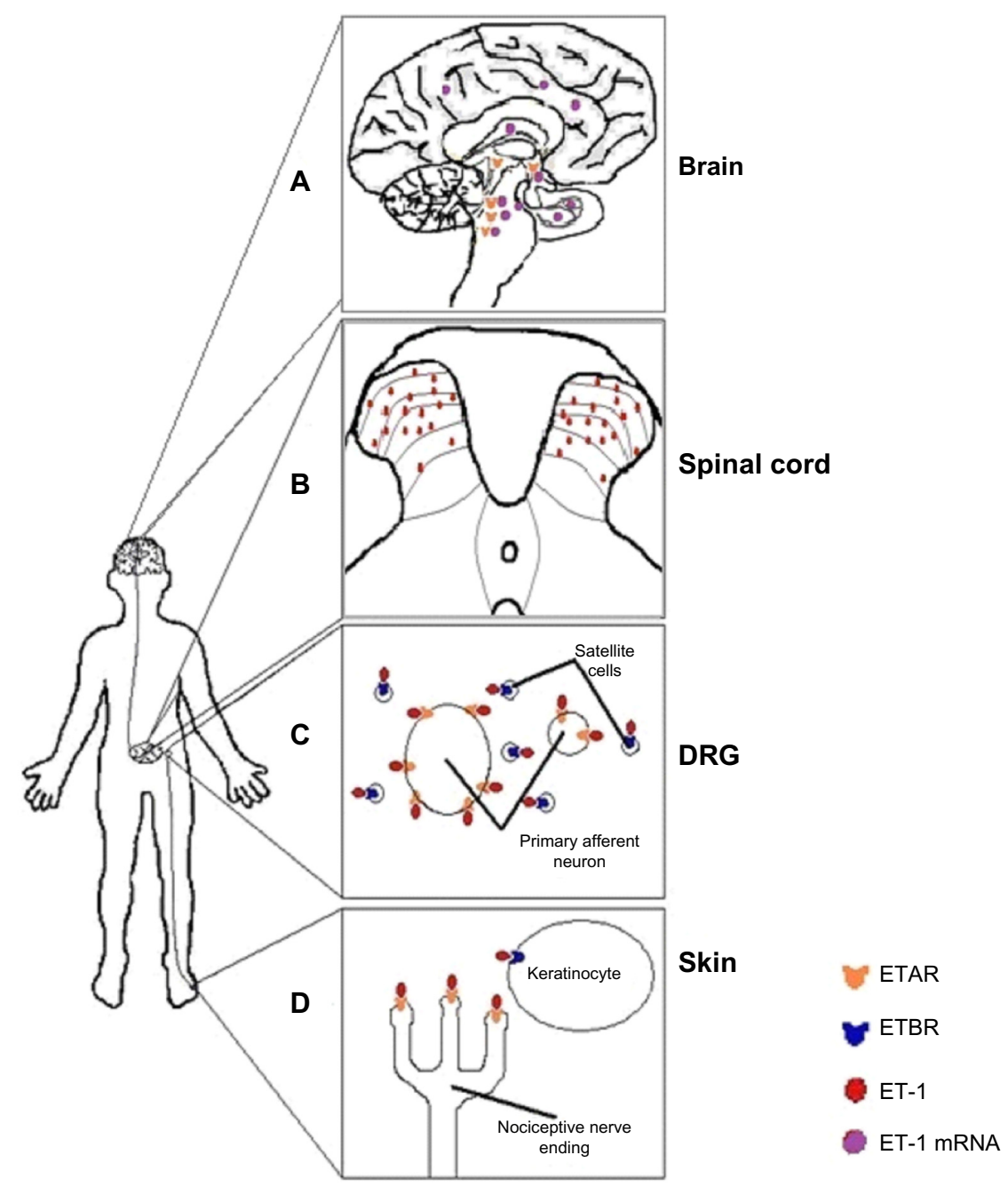

Figure I A schematic of the location of endothelin-I (ET-I) and endothelin receptors found throughout the pain pathway.

Notes: $\mathrm{ET}_{A}$ receptor (ETAR) and $\mathrm{ET}_{B}$ receptor (ETBR) show different patterns of expression within the nervous system. Four areas are shown in detail in which ET receptors are known to be expressed on different cell types. (A) ET-I mRNA and ETARs are found in several areas of the brain. ET-I mRNA is found in the hippocampus, amygdala, hypothalamus, raphe nucleus, locus coeruleus, cerebral cortex, pontine tegmentum, and lateral reticular formation. The ETAR is also found in the hypothalamus, locus coeruleus, pontine tegmentum, and reticular formation, as well as the substantia nigra. (B) In the spinal cord, ET-I immunoreactivity has been localized to laminae I-V. The expression of ET $T_{A}$ and ETBRs within the spinal cord laminae has thus far not been investigated. (C) In the dorsal root ganglion (DRG), ETAR immunoreactivity has been found on primary afferent sensory small and medium diameter neurons. ETBRs are localized on satellite cells and nonmyelinating Schwann cells. (D) Within the skin, ETARs are found on peripheral nerve endings in small- and medium-diameter neurons. ETBRs are found on endothelial cells, smooth muscle, and keratinocytes.

Abbreviation: $\mathrm{ET}$, endothelin-I.

hyperalgesia/allodynia, and thermal hyperalgesia/allodynia in dogs, rats, and mice. ${ }^{46-49}$ ET-1 has been shown to directly activate nociceptors in humans and animals. ${ }^{50,51}$ In addition, ET-1 potentiates nociception induced by other algogens such as formalin, serotonin, and capsaicin. ${ }^{52}$ Similar to other algogens, central administration of ET-1 has opposite effects and produces antinociception. ${ }^{53}$

\section{Human studies}

In human volunteers, ET-1 $(125 \mu \mathrm{g})$ administered into the brachial artery produced a sensation of heat, followed by vomiting and sweating and a deep muscular pain, with maximum severity at 2 hours and resolution at 10 hours; the pain was intensified by touch and muscular contractions. ${ }^{5}$ Lower doses of ET-1 $(12.5-50 \mu \mathrm{g})$ administered intradermally into the forearm produced intense itching, erythema, increased sensitivity to pinching, and pressure tenderness that subsided after 2 hours. ${ }^{46}$ In a similar study, intradermal administration of ET-1 (100 or $10 \mathrm{ng}$ ) resulted in spontaneous ongoing pain, with maximal pain score within 1 minute, and returned to normal after 30-60 minutes. ${ }^{49}$ At these doses, tenderness to mechanical stimulation (von Frey filaments) and cold hyperalgesia developed and outlasted the observation period of 120 minutes; heat hyperalgesia did not develop. ${ }^{49}$ Similar to intradermal, intracutaneous administration of ET-1 (25 ng- $0.25 \mathrm{pg})$ produced burning and stinging pain in 
9 of 34 subjects, itch sensation in 11 of 34 , and a mixture of both sensations in 14 of 34 subjects. ${ }^{51}$ These studies indicate that arterial administration of ET-1 produced long-lasting allodynia and deep muscular pain. Similarly, dermal administration of ET-1 produced itching and mechanical allodynia in low doses, whereas moderate doses produced spontaneous pain, mechanical hyperalgesia, and cold hyperalgesia (summarized in Table 2). ${ }^{46,49,51}$

Single-fiber recordings from the peroneal nerve of human participants showed that ET-1 (25 and $2.5 \mathrm{ng}$ ) produced activity in $65 \%$ of mechanosensitive, but not mechanoinsensitive, fibers with up to a third of the fibers having long-lasting responses (up to 15 minutes). ${ }^{51}$ Both fiber types showed sensitization to heat after ET-1 injection, with $62 \%$ of mechanosensitive fibers responding and $46 \%$ of mechanoinsensitive fibers. ${ }^{51}$ It is also interesting that ET-1 produced a different pattern of activity compared with the algogens capsaicin and histamine. In contrast to the long-lasting responses in mechanosensitive fibers after ET-1 administration, capsaicin and histamine cause short bursts of activity in mechanosensitive fibers and longer-lasting activation patterns in mechano-insensitive fibers. ${ }^{54}$ Thus, these studies suggest that ET-1 directly induces pain via mechanosensitive C-fibers and heat sensitization via both mechanosensitive and mechano-insensitive fibers. The firing pattern suggests that the mechanism of the pain-inducing actions of ET-1 is different from those of capsaicin and histamine.

\section{Rodent studies: spontaneous nociceptive behaviors}

As in humans, exogenous administration of ET-1 produces spontaneous pain-associated behaviors, as well as thermal and mechanical hyperalgesia and allodynia in rodents.

Table 2 Effect of endothelin-I administration in humans

\begin{tabular}{|c|c|c|c|}
\hline $\begin{array}{l}\text { Route of } \\
\text { administration }\end{array}$ & Dose & Symptoms & Reference \\
\hline Intraarterial & High & $\begin{array}{l}\text { Vomiting, sweating, deep } \\
\text { muscular pain }\end{array}$ & 5 \\
\hline Intradermal & Moderate & $\begin{array}{l}\text { Intense itching, erythema, } \\
\text { increased sensitivity } \\
\text { to mechanical stimuli, } \\
\text { pressure tenderness }\end{array}$ & 46 \\
\hline Intradermal & Low & $\begin{array}{l}\text { Spontaneous pain, } \\
\text { increased sensitivity to } \\
\text { mechanical stimuli, cold } \\
\text { hyperalgesia }\end{array}$ & 49 \\
\hline Intracutaneous & Low & $\begin{array}{l}\text { Burning and stinging pain, } \\
\text { itching }\end{array}$ & 51 \\
\hline
\end{tabular}

Notes: Defined doses: high, $>60 \mu \mathrm{g}$; moderate, I-59 $\mu \mathrm{g}$; and low, $<0.9 \mu \mathrm{g}$.
Intradermal administration of high doses of ET-1 produces $\mathrm{C}$ and $A \delta$ fiber activity as well as activity in a subpopulation of $\mathrm{A} \beta$ fibers. ${ }^{50}$ In general, $\mathrm{C}$ and $\mathrm{A} \delta$ fibers relay nociceptive information, whereas $A \beta$ fibers relay nonpainful tactile information. Flinching behaviors are absent when epinephrine (vasoconstrictor) alone is applied or when ET-1 is applied to surrounding muscle not innervated by the sciatic nerve. ${ }^{55}$ This finding lends further support to ET-1-induced nociception being independent from its vasoconstrictor effects and is likely through direct activation of nociceptors. In addition to causing spontaneous behaviors after a single subcutaneous administration, a second administration of ET-1 1 day later produces desensitization in the same paw and sensitization in the contralateral paw, dependent on afferent transmission. ${ }^{56}$

In the majority of studies, spontaneous ET-1-induced abdominal constrictions and ET-1-induced hind paw licking or flinching in the glabrous skin are mediated by the $\mathrm{ET}_{\mathrm{A}}$ receptor. ${ }^{46,47,50,57-61}$ In contrast, ET-1 administration into the hairy skin induces transient antinociception mediated by the $\mathrm{ET}_{\mathrm{B}}$ receptor. ${ }^{62}$

Species differences appear when examining the role of $\mathrm{ET}_{\mathrm{B}}$ receptors in ET-1-induced nociception. In mice, $\mathrm{ET}_{\mathrm{B}}$ receptors have no effects in ET-1-induced licking behavior. ${ }^{58,60}$ In the mouse cheek model, ET-1 causes both pruritic and nociceptive behaviors, and injection of an $\mathrm{ET}_{\mathrm{B}}$ antagonist causes potentiation of these behaviors, whereas coinjection of an $\mathrm{ET}_{\mathrm{A}}$ antagonist with the $\mathrm{ET}_{\mathrm{B}}$ antagonist significantly attenuates both behaviors. ${ }^{63}$ In contrast, in rats, agonists of the $\mathrm{ET}_{\mathrm{B}}$ receptor have antinociceptive effects, which are dependent on endogenous opioid release..$^{50,59,61,64}$ Activation of $\mathrm{ET}_{\mathrm{B}}$ receptors on keratinocytes induces the release of $\beta$-endorphins, which activate $\mu$-opioid receptors on nearby nociceptors, causing hyperpolarization and, ultimately, a decrease in nociception (Figure 2) ${ }^{64}$

\section{Rodent studies: thermal and mechanical hyperalgesia}

Similar to studies in humans, low doses of ET-1 produce a localized mechanical hyperalgesia in rodents. ${ }^{46,65,66}$ At higher doses, ET-1 produces a systemic mechanical hyperalgesia in both the ipsilateral and contralateral hindpaws. ${ }^{56} \mathrm{ET}_{\mathrm{B}}$ receptor activation mediates the mechanical hyperalgesia induced by high doses of ET-1, which is in contrast to the analgesic activity of $\mathrm{ET}_{\mathrm{B}}$ receptor activation in ET-1induced spontaneous nociception. ${ }^{67,68}$ In mouse models of inflammatory pain, $\mathrm{ET}_{\mathrm{A}}$ receptors are involved in both thermal and mechanical hyperalgesia, whereas $\mathrm{ET}_{\mathrm{B}}$ receptors are only involved in mechanical hyperalgesia. ${ }^{67}$ It has also 


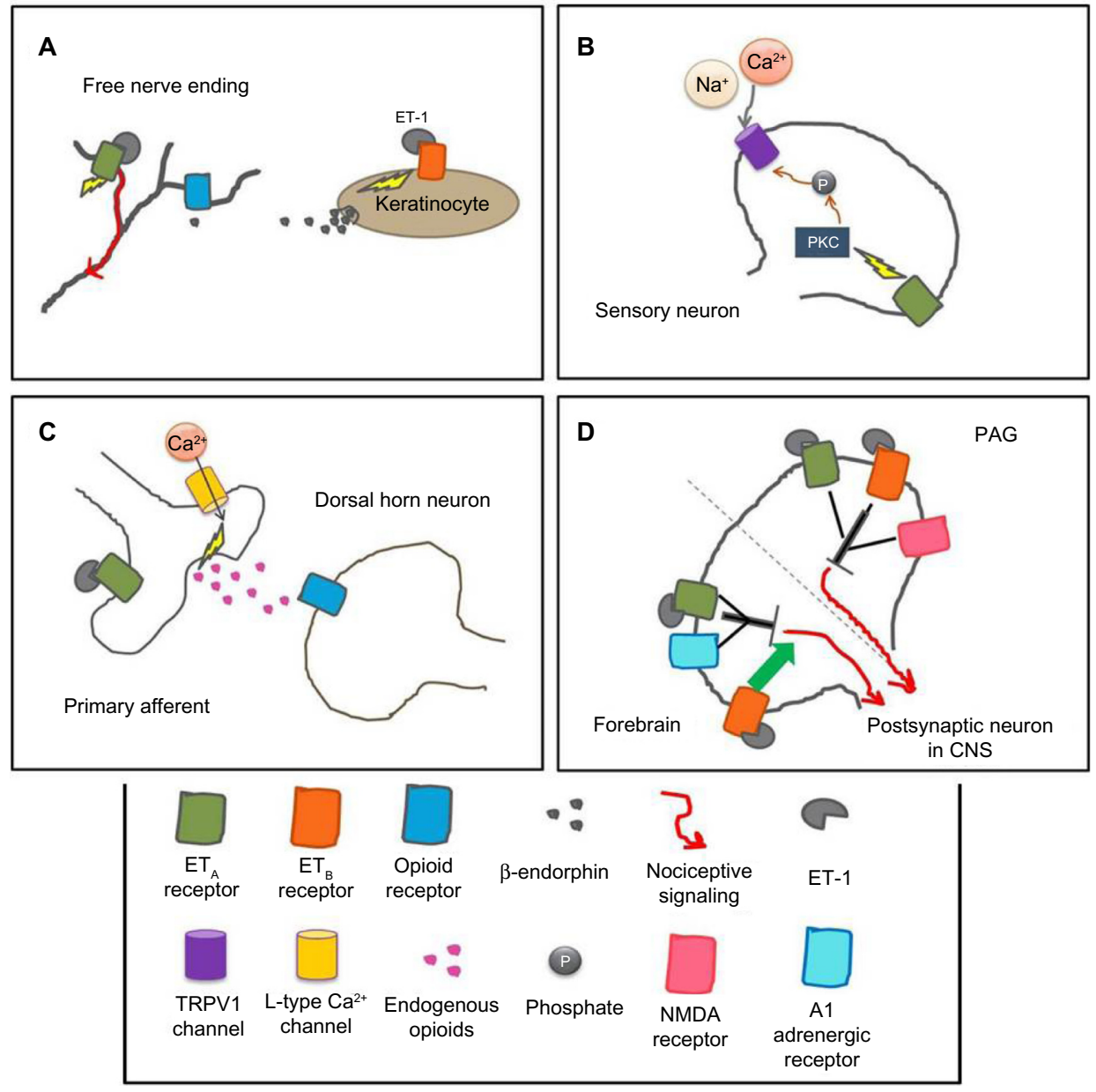

Figure 2 Mechanisms of the endothelin system in various parts of the pain pathway at the cellular level in rodents.

Notes: (A) Endothelin-I $\left(E_{A}\right)$ receptors located on nociceptors located in the skin mediate nociception; however, $\mathrm{ET}_{B}$ receptors located on keratinocytes mediate antinociception by causing the release of $\beta$-endorphin from keratinocytes, which activate opioid receptors on nociceptors, thereby decreasing the signal. (B) When a sensory neuron is stimulated by capsaicin and $\mathrm{ET}-\mathrm{I}, \mathrm{ET}_{\mathrm{A}}$ receptors activate protein kinase $\mathrm{C}$, which causes the phosphorylation of transient receptor potential vanilloid subfamily channels, thereby allowing cations to flow through the channel, causing potentiation of the signal. (C) Intrathecal administration of ET-I causes the activation of L-type Ca ${ }^{2+}$ channels and the release of endogenous opioids, thereby causing analgesia. (D) ET-I administration into the PAG produces analgesia via the $\mathrm{ET}_{\mathrm{A}}$ and $\mathrm{ET}_{\mathrm{B}}$ receptors and is dependent on $\mathrm{N}$-methyl-D-aspartate activation. An intracerebroventricular injection of ET-I also elicits analgesia; this is mediated by the $\mathrm{ET}_{\mathrm{A}}$ receptor and $\alpha \mathrm{I}$ adrenergic receptor and antagonized by the $\mathrm{ET}_{\mathrm{B}}$ receptor.

Abbreviations: CNS, central nervous system; TRPVI, transient receptor potential vanilloid subfamily; NMDA, N-methyl-D-aspartate; PAG, periaqueductal gray; ET, endothelin-I.

been shown that calcitonin gene-related peptide (CGRP) and N-methyl-D-aspartate receptor antagonists can attenuate ET-1-induced mechanical sensitization. ${ }^{69}$ In addition, the mechanism involved in this mechanical hyperalgesia appears to be independent of ET-1-induced vasoconstriction, sympathetic nervous system activation, and prostaglandins. ${ }^{65}$

In humans, intradermal ET-1 induces thermal hyperalgesia by enhancing sensitivity of $\mathrm{C}$-fiber nociceptors to heat. ${ }^{51}$ Similarly in mice and rats, low doses of ET-1 have been reported to produce thermal hyperalgesia. ${ }^{56,60}$ Studies with $\mathrm{ET}_{\mathrm{A}}$ and $\mathrm{ET}_{\mathrm{B}}$ receptor antagonists generally support a prohyperalgesic role of the $\mathrm{ET}_{\mathrm{A}}$ receptor in thermal hyperalgesia and an unclear role for the $\mathrm{ET}_{\mathrm{B}}$ receptor. ${ }^{60,70,71}$ However, ET-1-induced thermal hyperalgesia occurs similarly in both conditional $\mathrm{ET}_{\mathrm{A}}$ knockout mice and control mice. ${ }^{72}$ This suggests that thermal hyperalgesia occurs independent of $\mathrm{ET}_{\mathrm{A}}$ receptors while highlighting the need for further study.

The transient receptor potential vanilloid subfamily (TRPV1) channel may play a role in ET-1-induced thermal hyperalgesia. In mice with conditional deletion of the $\mathrm{ET}_{\mathrm{A}}$ receptor on sensory neurons, thermal and mechanical sensitivities were unaffected; however, capsaicin-induced nocifensive behaviors were significantly reduced. ${ }^{72}$ TRPV1 channels are colocalized with $\mathrm{ET}_{\mathrm{A}}$ receptors on sensory neurons in the DRG, and both endothelin receptors are co-localized with TRPV1 channels on neurons in the rat trigeminal ganglia. ${ }^{34,73}$ ET-1 potentiates capsaicin-induced TRPV1 currents via activation of PKCE..$^{73,74}$ Therefore, activation and sensitization of nociceptors by ET-1 may be mediated by $\mathrm{ET}_{\mathrm{A}}$ receptors activating $\mathrm{PKC} \varepsilon$, which targets 
TRPV1 channels (Figure 2). In support of this mechanism, TRPV1 knockout mice show reduced ET-1-induced thermal hyperalgesia. ${ }^{70}$ In addition, in HEK293 cells expressing both $\mathrm{ET}_{\mathrm{A}}$ and TRPV1 channels, ET-1 evokes inward current responses, which are not seen in cells expressing only $\mathrm{ET}_{\mathrm{A}}$ receptors. In HEK293 cells and in the skin, ET-1 leads to the phosphorylation of TRPV $1 .{ }^{70}$ Together, these results suggest there is an interaction between $\mathrm{ET}_{\mathrm{A}}$ and TRPV1 channels that may have pronociceptive effects.

\section{Rodent studies: potentiation of algogens}

Formalin, capsaicin, and serotonin are algogens that induce spontaneous nociceptive behaviors when administered subcutaneously in rodents. In rats and mice, ET-1, through $\mathrm{ET}_{\mathrm{A}}$ and $\mathrm{ET}_{\mathrm{B}}$ receptors, potentiates formalin-induced nociception; this effect is also seen contralaterally in rats. ${ }^{52,56,71}$ In addition, ET-1 potentiates capsaicin-induced nociception via the $\mathrm{ET}_{\mathrm{A}}$ receptor ${ }^{75}$ and enhances capsaicin-stimulated release of CGRP in sensory neurons and c-Fos expression in the dorsal horn of the spinal cord. ${ }^{69,76}$ Serotonin-primed capsaicininduced nociception is abolished by administration of high doses of ET-1 or an $\mathrm{ET}_{\mathrm{B}}$ receptor agonist. ${ }^{75}$ The general hypothesis is that at lower ET-1 doses, the $\mathrm{ET}_{\mathrm{A}}$ receptor potentiates capsaicin-induced hyperalgesia, but at higher ET-1 doses, the $\mathrm{ET}_{\mathrm{B}}$ receptor mediates an antinociceptive effect. This is similar to the working model, in which a high dose of ET-1 induces algesia via ET $_{\mathrm{A}}$ receptors and a concurrent analgesic effect mediated via $\mathrm{ET}_{\mathrm{B}}$ receptors. ${ }^{55}$

\section{Rodent studies: acute postsurgical pain}

The endothelins have been implicated in postsurgical pain, using a rat model of postincisional pain in which both primary and secondary mechanical allodynia and hyperalgesia develop. ${ }^{77}$ The $\mathrm{ET}_{\mathrm{A}}$ receptor mediates primary and secondary mechanical allodynia. In contrast, the $\mathrm{ET}_{\mathrm{A}}$ receptor mediates secondary hyperalgesia, but not primary hyperalgesia. ${ }^{77}$ These findings suggest that local blockade of $\mathrm{ET}_{\mathrm{A}}$ receptors before incision may be a viable therapeutic approach for reducing postincisional pain.

\section{ET-I in the central nervous system}

In contrast to peripheral studies showing ET-1 as an algogen, administration of ET-1 into the central nervous system is often antinociceptive. Intrathecal ET-1 produces dosedependent thermal analgesia in mice that is reduced by the nonspecific opioid receptor antagonist naloxone or a $\delta$-opioid receptor antagonist. ${ }^{78}$ The analgesic actions of intrathecal ET-1 administration occur through activation of L-type $\mathrm{Ca}^{2+}$ channels and the release of endogenous opioids (Figure 2). ${ }^{78}$ Although ET-1 administered peripherally enhances formalin-induced nociception, intrathecal ET-1 decreases formalin-induced nociception via the $\mathrm{ET}_{\mathrm{A}}$ receptor. ${ }^{79} \mathrm{Simi}-$ larly, transgenic mice that overexpress ET-1 in astrocytes have a significant decrease in nociceptive behaviors during the second phase of the formalin test compared with nontransgenic mice, further supporting an antinociceptive role for ET-1 in the spinal cord. ${ }^{80}$

Administration of ET-1 into the periaqueductal gray (PAG) of mice produces thermal analgesia mediated by both the $\mathrm{ET}_{\mathrm{A}}$ and $\mathrm{ET}_{\mathrm{B}}$ receptors and dependent on N-methyl-D-aspartate activation (Figure 2). ${ }^{53,81}$ Intracerebroventricular ET-1 dose-dependently produces analgesia to thermal stimuli, ${ }^{82}$ which is mediated by the $\mathrm{ET}_{\mathrm{A}}$ receptor and the $\alpha 1$ adrenergic receptor and antagonized by the $\mathrm{ET}_{\mathrm{B}}$ receptor (Figure 2). ${ }^{82}$ Thus, ET-1's analgesic actions in the brain may be mediated via $\mathrm{ET}_{\mathrm{A}}$ and $\mathrm{ET}_{\mathrm{B}}$ receptors through a noradrenergic pathway that activates a descending inhibitory pathway to the spinal cord, possibly through the release of endogenous opioids.

\section{Age and sex differences}

Cardiovascular studies suggest that the biological activity of ET-1 in humans varies depending on age, sex, and concentration of ET-1. Some of this variability results from sex- and age-dependent expression of $\mathrm{ET}_{\mathrm{A}}$ and $\mathrm{ET}_{\mathrm{B}}$ receptors. In the saphenous vein, postmenopausal women demonstrate a $1: 1$ ratio of $\mathrm{ET}_{\mathrm{A}}: \mathrm{ET}_{\mathrm{B}}$ expression compared with age-matched male ratios of 3:1 expression. ${ }^{83}$ Age-specific expression patterns have also been demonstrated, with infants having higher peripheral levels of ET- $1^{84}$ and a higher density of endothelin receptors in the heart compared with older children and adults, ${ }^{85}$ suggesting a decrease in ET-1 activity after infancy.

Similarly, adult rodents show sex differences in the onset of ET-1-induced mechanical hyperalgesia, with a more rapid onset of hyperalgesia in adult males and ovariectomized females when compared with intact females. ${ }^{86}$ In addition, male and ovariectomized female rats, but not intact females, show progressively increased hyperalgesia after repeated mechanical stimulation. In neonatal rats, ET-1-induced spontaneous licking and flinching behaviors are age- and sex-dependent. ${ }^{61}$ ET-1-induced nociceptive behaviors are significantly greater in younger animals and decrease with age. At early ages, males show increased nociception compared with females. The sex difference in ET-1-induced spontaneous nociception decreases with maturation. Similarly, an age- and sex-dependence was observed for the priming effect 
of ET-1 on subsequent ET-1 exposures, which is important in certain disease states in which there are repeated exposures to ET-1, such as sickle cell disease. Exposure to ET-1 during the neonatal period produced an increase in nociceptive behaviors in response to a second exposure to ET-1 4 days later in male rats ${ }^{87}$ In contrast, a priming exposure to ET-1 in neonatal female rats decreased nociceptive behaviors when exposed to a second administration of ET- $1 .{ }^{87}$ Furthermore, sensitization to a second ET-1 exposure was also observed in 2-month-old male rats, but the desensitization to a second ET-1 exposure was not observed in older females. This suggests a long-lasting sensitization in male rats exposed to ET-1 in the neonatal period and a short-lasting desensitization in female rats. A subsequent study showed that a first exposure to ET-1 at 3 weeks after birth did not show the same priming to a second exposure to ET-1 as found in the neonatal rats, suggesting a window of vulnerability for ET-1-induced priming of nociceptive responses.

Mechanistically, ET-1-induced priming in neonatal males decreased $\mathrm{ET}_{\mathrm{B}}$ receptor expression in the skin and sensitized the rats to subsequent ET-1 administration. In neonatal females, ET-1-induced priming increased $\mathrm{ET}_{\mathrm{B}}$ receptor expression in the skin and desensitized the rats to subsequent ET-1 administration. No changes in $\mathrm{ET}_{\mathrm{A}}$ or $\mu$-opioid receptor expression were found ${ }^{87}$ Furthermore, ET-1-induced sensitization in neonatal males could be prevented with morphine administration at the time of the priming dose of ET-1, which prevented the downregulation of $\mathrm{ET}_{\mathrm{B}}$ receptor expression. These studies highlight the importance of the $\mathrm{ET}_{\mathrm{A}}$-to-ET receptor ratio in the modulation of ET-1-induced pain.

\section{ET- I in inflammatory pain}

Endogenous ET-1 is implicated as a mediator in inflammatory pain. ET-1 is released during the inflammatory process, and its production is stimulated by the inflammatory mediators interleukin $1 \beta$, tumor necrosis factor $\alpha$, and tumor necrosis factor $\beta .^{88,89}$ In addition, human neutrophils synthesize ET-1, providing an additional source of ET-1 in inflammatory states. ${ }^{77}$ Both acute (carrageenan) and chronic (complete Freund's adjuvant) inflammatory rodent models produce thermal and mechanical hyperalgesia that is modulated by endogenous ET-1 signaling. Thermal hyperalgesia in these mouse models appear to be primarily modulated by $\mathrm{ET}_{\mathrm{A}}$ receptors. ${ }^{67}$ However, in a rat complete Freund's adjuvant model, both endothelin receptors appear to be involved in modulating thermal hyperalgesia with a more pronounced role for the $\mathrm{ET}_{\mathrm{B}}$ receptor. ${ }^{90}$ Both endothelin receptors are also involved in modulating carrageenan- and complete
Freund's adjuvant-induced mechanical hyperalgesia. ${ }^{67,90}$ One theory for the role of the $\mathrm{ET}_{\mathrm{B}}$ receptor in inflammatory pain is that activation of the $\mathrm{ET}_{\mathrm{B}}$ receptor causes the release of tumor necrosis factor $\alpha$ and interleukin 6 , which activate nociceptors to produce mechanical hyperalgesia. Nociception induced by ET-1 in inflammatory pain is mediated via different receptors, depending on the type of inflammation. ${ }^{91,92}$ In the naïve rat joint, $\mathrm{ET}_{\mathrm{A}}$ receptors mediate inflammation; in the carrageenan-primed joint, both endothelin receptors are involved; and in the carrageenan-primed joint challenged with lipopolysaccharide, the $\mathrm{ET}_{\mathrm{B}}$ receptor mediates the effects. These studies show that the interaction between inflammation and the endothelin system is highly complex and depends on the specifics of the inflammation.

One common inflammatory pain condition is arthritis, and it has been shown that ET-1 plasma levels are increased in patients with rheumatoid arthritis and osteoarthritis compared with control patients. ${ }^{89}$ ET- 1 levels are also higher in patients with active rheumatoid arthritis compared with those with inactive rheumatoid arthritis. ${ }^{89}$ In a mouse model of antigeninduced arthritis, both the genes encoding for ET-1 and the $\mathrm{ET}_{\mathrm{A}}$ receptor were upregulated in lumbar DRGs. ${ }^{93} \mathrm{~A}$ mixed $\mathrm{ET}_{\mathrm{A}} / \mathrm{ET}_{\mathrm{B}}$ receptor antagonist inhibited acute and chronic inflammation during antigen-induced arthritis flare-up reactions. Similarly, in an ovalbumin-induced mouse model of chronic arthritis, a mixed $\mathrm{ET}_{\mathrm{A}} / \mathrm{ET}_{\mathrm{B}}$ receptor antagonist or a selective $\mathrm{ET}_{\mathrm{A}}$ receptor antagonist reduced nociceptive behavior, whereas a selective $\mathrm{ET}_{\mathrm{B}}$ receptor antagonist enhanced nociception. ${ }^{94}$ These studies suggest that the pain caused by arthritis may be alleviated via ET receptor antagonists; however, the dichotomy of $\mathrm{ET}_{\mathrm{B}}$ receptor actions in these models remains to be elucidated.

\section{Specific diseases Cancer}

ET-1 protein or mRNA is hypersecreted by many cancer types, such as prostate, breast, pancreatic, colon cancer, and human oral squamous carcinoma cell lines. ${ }^{4,95,96}$ ET-1 is believed to be involved in many aspects of cancer progression, such as tumor growth and cell proliferation. ${ }^{6}$ Pain is prevalent in about $70 \%$ of people with metastatic cancers such as prostate and breast cancer. ${ }^{97}$ Exogenous application of ET-1 in animal models of cancer has been found to potentiate cancer-induced nociception and sensitization of C-fibers to heat via activation of $\mathrm{ET}_{\mathrm{A}}$ receptors, a similar pathway as that seen in ET-1-induced potentiation of formalin- and capsaicin-induced nociception. ${ }^{98,99}$ It has been shown that the concentration of ET-1 has a more direct correlation to 
pain levels than the size of the tumor in mice, ${ }^{100}$ illustrating the importance of evaluating algogens released by cancerous tumors, such as ET-1, to identify novel therapeutic targets to treat cancer pain.

Broadly speaking, there are two categories of endothelinderived tumors: those that hypersecrete ET-1, upregulate $\mathrm{ET}_{\mathrm{A}}$ receptors, and moderately downregulate $\mathrm{ET}_{\mathrm{B}}$ receptors (colon, ovarian, pancreatic, prostate, and renal cell carcinoma), and those that hypersecrete ET-1, upregulate $\mathrm{ET}_{\mathrm{B}}$ receptors, and moderately downregulate $\mathrm{ET}_{\mathrm{A}}$ receptors (lung and breast). ${ }^{6}$ Several types of cancer cells are known to produce ET-1 in culture or after injection into animal models, as indicated by increased ET-1 protein and/or mRNA levels. ${ }^{96,101-104}$ These high levels of ET-1 seem to correlate with increases in nociceptive behaviors, mechanical hyperalgesia, and mechanical allodynia, which are mediated by $\mathrm{ET}_{\mathrm{A}}$ receptors. ${ }^{72,101-104}$ In murine models of cancer pain, thermal hyperalgesia is significantly increased, which may be mediated by $\mathrm{ET}_{\mathrm{B}}$ receptors in the early stage and the $\mathrm{ET}_{\mathrm{A}}$ receptor in long-lasting hyperalgesia. ${ }^{96,105}$ Clinical studies using the $\mathrm{ET}_{\mathrm{A}}$ receptor antagonist atrasentan have already shown some promise in improving cancer-related pain. ${ }^{4}$ These results suggest that targeting the endothelin receptors may prove a novel painreducing therapy in cancer pain.

\section{Diabetes}

Patients with diabetes often develop sensory neuropathy characterized by alterations in their ability to sense the environment. Diabetic neuropathy can manifest as a painless syndrome, in which there is a loss of touch, temperature, and pain sensation, or as a painful syndrome, in which thermal, mechanical, and tactile hyperalgesia and/or allodynia are present. ${ }^{35}$ The ET-1 system has been affected in diabetic neuropathy in experimental animals. In a model of type 1 diabetes using streptozotocin (STZ), plasma ET-1 immunoreactivity is significantly increased and $\mathrm{ET}_{\mathrm{B}}$ receptors have an abnormal appearance on satellite cells, in addition to a decrease in expression. ${ }^{35,106}$ STZ-treated animals and transgenic rats $\left(\mathrm{DBH}-\mathrm{ET}_{\mathrm{B}}: \mathrm{ET}_{\mathrm{B}}^{\mathrm{sl} / \mathrm{sl}}\right)$ exhibit significant increases in both mechanical hyperalgesia and tactile allodynia. ${ }^{35}$ Tactile allodynia of STZ-treated rats can be reduced with acute or chronic inhibition of $\mathrm{ET}_{\mathrm{A}}$ receptors, but not $\mathrm{ET}_{\mathrm{B}}$ receptors alone or effectively with inhibition of both receptors. ${ }^{107}$ Intrathecal administration of ET-1 produces antinociception in control but not STZ-treated mice, unless the dose of ET-1 is reduced, which produces dose-dependent antinociception in STZ-treated but not control mice. ${ }^{108}$ This suggests there may be an upregulation of endothelin receptors in the STZ model of diabetic mice. ET-1 and its receptors are implicated in diabetic neuropathies, as suggested in the aforementioned animal models. The dichotomy of endothelin receptors still remains to be fully characterized, and further investigation is needed. Use of endothelin receptor antagonists in the treatment of diabetic pain is yet to be researched in humans.

\section{Neuropathic pain}

Neuropathic pain is a type of chronic pain in which nerve damage has occurred, and it is often difficult to diagnose and treat effectively. The endothelin system has been implicated in being directly involved in the development of neuropathic-like pain in animal models. In a model of trigeminal neuralgia, inducing injury to the trigeminal nerve results in mechanical allodynia that is only reduced by $\mathrm{ET}_{\mathrm{B}}$ receptor antagonism, as opposed to an $\mathrm{ET}_{\mathrm{A}}$ or mixed receptor antagonist. ${ }^{109}$ Cold hyperalgesia also develops in this model, and this effect is suppressed by both $\mathrm{ET}_{\mathrm{B}}$ and $\mathrm{ET}_{\mathrm{A}}$ receptor antagonists. ${ }^{110}$ In a mouse model of complex regional pain syndrome type 1 , ET-1 administration causes hypersensitivity and an $\mathrm{ET}_{\mathrm{A}}$ receptor antagonist reduces ET-1-induced sustained nociceptive behaviors, whereas an $\mathrm{ET}_{\mathrm{B}}$ receptor antagonist enhances those behaviors. ${ }^{111}$ In the chronic constriction injury and spinal nerve ligation (SNL) peripheral nerve injury models, the $\mathrm{ET}_{\mathrm{A}}$ and both $\mathrm{ET}_{\mathrm{A}}$ and $\mathrm{ET}_{\mathrm{B}}$ receptors, respectively, play important roles in the development of nociceptive-associated behaviors. ${ }^{112,113}$ In the chronic constriction injury model, ET-1 mRNA and $\mathrm{ET}_{\mathrm{A}}$ receptor $\mathrm{mRNA}$ and protein are increased in the nerve and at the site of injury. ${ }^{12}$ In the SNL model, both $\mathrm{ET}_{\mathrm{A}}$ and $\mathrm{ET}_{\mathrm{B}}$ receptor proteins are increased in the injured nerve. ${ }^{113}$ In rats with SNL, injection of ET-1 into the hind paw causes significantly greater nociceptive behaviors compared with sham animals, which are attenuated by an $\mathrm{ET}_{\mathrm{A}}$ receptor antagonist. SNL also causes an enhancement of ET-1-induced increases in intracellular calcium in neuronal cells, which may help explain the increase in nociceptive behaviors that develops after ET-1 administration in those animals. ${ }^{113}$ These studies suggest the endothelin system may provide an effective target in pain therapy for neuropathic pain conditions.

\section{Gastrointestinal disorders}

The endothelin system has been implicated in playing a role in some forms of visceral pain. In mice, an intraperitoneal injection of ET-1 causes rapid onset of abdominal constrictions. ${ }^{114}$ Mice lacking either one or both copies of the $\mathrm{ET}_{\mathrm{B}}$ receptor gene have significantly reduced or absent abdominal constrictions in response to phenylbenzoquinone, which is used to elicit overt nociception in 
the abdomen. ${ }^{115}$ The endothelin system is also known to play an important role in the development of the enteric nervous system. When the ET-3 or $\mathrm{ET}_{\mathrm{B}}$ receptor gene is deleted, mice develop a condition similar to Hirschsprung's disease in humans, in which the enteric nervous system fails to innervate the colorectum, leading to distension of the bowel. ${ }^{116}$ These mice also display a lack of nociceptive response to distension of the rectum compared with wildtype mice, which is thought to be a result of an impairment in the signaling from low-threshold, wide-dynamic range afferents from the rectum. ${ }^{116}$

In humans, ET-1 has been found to be elevated in patients with active inflammatory bowel disease, ${ }^{117}$ Crohn's disease, and ulcerative colitis, ${ }^{118,119}$ which are gastrointestinal conditions known to have pain as a major symptom, compared with controls. Although the endothelin system has not been directly linked to the pain associated with these conditions, it may be worth exploring, as ET-1 has been implicated in other inflammatory pain conditions.

\section{Sickle cell disease}

Children and adults with sickle cell disease (SCD) experience recurrent, unpredictable painful vasoocclusive episodes. The endothelin pathway has been implicated in this type of painful episode, both as a trigger in the onset of vasoocclusive episodes and as a direct activator of nociceptors. ${ }^{57,114}$ Red blood cells and sickled red blood cells from homogenous sickle cell patients cause an increase in the release of ET-1 and the induction of ET-1 mRNA, respectively, from endothelial cells, suggesting ET-1 may be an important factor in facilitating vasoocclusive episodes. ${ }^{120,121}$ In endothelial cells exposed to plasma from SCD patients at different disease stages, there is an increased production of ET-1 during acute chest syndrome, with the highest levels of ET-1 production occurring with samples that were taken 4 days before hospital admittance for vasoocclusive episodes. ${ }^{122}$ Increased circulating ET-1 levels have been demonstrated clinically in sickle cell patients during vasoocclusive episodes. ${ }^{122-126}$ Hydroxyurea is used in the treatment of painful vasoocclusive episodes, and it has been shown to downregulate ET-1 gene expression in endothelial cells. ${ }^{127,128}$ Children with SCD treated with hydroxyurea have been shown to have levels of circulating ET-1 that were two times lower than those of untreated SCD children or controls. ${ }^{129}$ Current research is being conducted to determine the relationship of the endothelin pathway and painful vasoocclusive episodes.

Vasoocclusive pain has been modeled in rats by injecting endothelin in the hind paw. One hypothesis is that prior exposure to ET-1 will alter behavioral responses to subsequent ET-1 administration in a sex-specific manner. Young male rats become sensitized to pain after being "primed" with ET-1, whereas females appear to become desensitized to pain after being primed with ET-1. ${ }^{61}$ Additional results suggest that these differences between males and females may be a result of changes in the $\mathrm{ET}_{\mathrm{B}}$ receptor. ${ }^{87}$ In a mouse model of SCD, the ET-1 gene has been found to be upregulated after chronic exposure to hypoxia, and a mixed $\mathrm{ET}_{\mathrm{A}} / \mathrm{ET}_{\mathrm{B}}$ receptor antagonist can prevent hypoxia-induced vasoocclusive episodes. ${ }^{130,131}$ Clinical studies have also been done to examine correlations between ET-1 levels and pain levels. Elevated plasma levels of ET-1 have been found in symptomatic SCD patients, and these levels increase with increased pain ratings. ${ }^{124}$ In these patients, ET-1 levels decreased with a decrease in pain levels and a subsiding of symptoms but did not reach levels seen in healthy controls. Similarly, high plasma levels of ET-1 and Big Endothelin, the precursor of ET-1, in children with SCD were positively correlated with higher baseline pain ratings and greater baseline pain responses, respectively, before venipuncture. ${ }^{132}$

In addition to contributing to painful episodes in SCD, the endothelin system may also be involved in the sickling of red blood cells and other complications of SCD. ET-1 has been shown to play a role in modulating the activity of the Gardos channel, which is important in sickle erythrocyte dehydration, in erythrocytes via the $\mathrm{ET}_{\mathrm{B}}$ receptor. ${ }^{133-135}$ A polymorphism in the gene encoding for ET-1 is associated with the occurrence of vasoocclusive crisis and acute chest syndrome, a common complication of SCD, in children with SCD. ${ }^{136}$ A disruption of nitric oxide homeostasis has been implicated in SCD; one of its many consequences is an increase in ET-1. ${ }^{137-139}$ Nitric oxide that is derived from endothelial cells regulates ET-1 expression, which contributes to the modulation of vessel tone. ${ }^{139}$

These studies expose the need for a better understanding of the role of the endothelin system in SCD and the pain associated with it, so that alternative treatments for SCD can be explored.

\section{Morphine analgesia/tolerance}

Endothelin antagonists have not only been found to be analgesic themselves but have also been shown to enhance the analgesia of morphine. Centrally administered $\mathrm{ET}_{\mathrm{A}}$ receptor antagonists have been shown to increase morphine analgesia. ${ }^{140}$ Similarly, centrally administrated $\mathrm{ET}_{\mathrm{A}}$ receptor antagonists may reverse opioid tolerance and rescue opioid analgesia. ${ }^{140}$ In contrast, an $\mathrm{ET}_{\mathrm{B}}$ receptor agonist does not 
increase morphine analgesia. ${ }^{141}$ These studies suggest that centrally administered $\mathrm{ET}_{\mathrm{A}}$ receptor antagonists may enhance and extend the time of morphine analgesia, in addition to decreasing morphine tolerance. Thus, $\mathrm{ET}_{\mathrm{A}}$ receptor antagonists may not only reduce pain experienced but may also aid other analgesics in combination therapies.

\section{Implications to human disease and conclusions}

The current research investigating the nociceptive effects of ET-1 in rodent models all concur that ET-1 receptors may prove a novel target for pain-relieving therapies. Studies using antagonists have shown that activation of $\mathrm{ET}_{\mathrm{A}}$ receptors in the periphery is pronociceptive (Table 3); therefore, blocking this receptor would provide pain relief. Identifying the actions of the $\mathrm{ET}_{\mathrm{B}}$ receptor presents a more challenging feat (Table 1 ). The effects of the receptor appear to be pronociceptive in mediating mechanical hyperalgesia in low and high doses. ${ }^{46,65,68}$ Conversely, this receptor appears to be analgesic when high doses of ET-1 are administered in the vicinity of keratinocytes. ${ }^{59}$ In other animal models, it appears that activation of the $\mathrm{ET}_{\mathrm{B}}$ receptor has no effect on nociception (Table 3). ${ }^{58,60}$ These seemingly contradictory findings may be the result of differences in the species used, sex differences, ET-1 doses, nociceptive testing procedures, or other such caveats. Therefore, further studies are needed to elucidate the value of selective $\mathrm{ET}_{\mathrm{B}}$ receptor antagonists and agonists in pain-reduction therapies.

Several human disease states are candidates for $\mathrm{ET}_{\mathrm{A}}$ receptor antagonist pain reduction therapies. Diseases implicated include diabetic neuropathies, trigeminal neuralgia, crushed nerve syndrome, chronic arthritis, and many types of cancer pain (bone, oral, prostate, and breast). In addition to these diseases, several others have been implicated as ET-1 receptor antagonist clinical trial candidates on the basis of their overproduction of ET-1. Research on ET-1's involvement in several painful conditions such as sickle cell crisis, acute chest syndrome, complex regional pain syndrome, and Raynaud's syndrome are currently being investigated, with

Table 3 Participation of $\mathrm{ET}_{\mathrm{A}}$ and $\mathrm{ET}_{\mathrm{B}}$ receptors in different models

\begin{tabular}{|c|c|c|c|}
\hline Model & $\mathrm{ET}_{\mathrm{A}}$ receptor & $\mathrm{ET}_{\mathrm{B}}$ receptor & References \\
\hline \multicolumn{4}{|l|}{ Exogenous application of ET-I } \\
\hline Spontaneous hind paw flinching & Pronociceptive & Antinociceptive & $50,59,61$ \\
\hline Abdominal constriction & Pronociceptive & Not tested & $47,48,114$ \\
\hline Sciatic nerve application & Pronociceptive & Little response & 55 \\
\hline Nerve recordings & Pronociceptive & Antinociceptive & 50 \\
\hline Spontaneous licking & Pronociceptive & Not involved & 58,60 \\
\hline \multirow[t]{2}{*}{ Mechanical hyperalgesia } & Not involved & Pronociceptive & $46,65,68$ \\
\hline & Pronociceptive & Pronociceptive & 67 \\
\hline Thermal hyperalgesia & Pronociceptive & Not involved & 60 \\
\hline \multirow{2}{*}{ ET-I + formalin } & Phase I: mediates & Phase I: not involved & 52 \\
\hline & Phase II: mediates & Phase II: mediates & \\
\hline ET-I + capsaicin licking & Pronociceptive & Not involved & 75 \\
\hline Enhanced carrageenan paw elevation & Pronociceptive & Pronociceptive & 92 \\
\hline \multicolumn{4}{|l|}{ No exogenous ET-I application } \\
\hline Postsurgical mechanical hyperalgesia & Pronociceptive & Not tested & 77 \\
\hline Phenylbenzoquinone-induced & Not involved & Pronociceptive & 146 \\
\hline \multicolumn{4}{|l|}{ abdominal constriction } \\
\hline Pruritus & Not involved & Pronociceptive & 146 \\
\hline Inflammatory pain: thermal hyperalgesia & Pronociceptive & Not involved & 67 \\
\hline Inflammatory pain: mechanical hyperalgesia & Pronociceptive & Pronociceptive & 67 \\
\hline Primed inflammatory pain: paw elevation & Not involved & Pronociceptive & 91 \\
\hline \multicolumn{4}{|l|}{ Cancer } \\
\hline Sarcoma virus infected & Early and late thermal hyperalgesia & Early thermal hyperalgesia & 105 \\
\hline Sarcoma cells & Mediates nociception & - & 147 \\
\hline Bone cancer & Nociception & Analgesia & 102 \\
\hline Oral cancer & $\begin{array}{l}\text { Increase in nociception and mechanical } \\
\text { hyperalgesia via } \mathrm{ET}_{\mathrm{A}}\end{array}$ & - & 103 \\
\hline Skin cancer & Pronociceptive; mechanical allodynia & - & 104 \\
\hline Oral cancer melanoma & Pronociceptive in oral cancer model & & 100 \\
\hline
\end{tabular}

Abbreviation: $\mathrm{ET}$, endothelin-I. 
pain-relieving results being reported. For example, three patients with secondary Raynaud's phenomenon received the mixed $\mathrm{ET}_{\mathrm{A}} / \mathrm{ET}_{\mathrm{B}}$ receptor antagonist bosentan twice daily for 4 weeks, followed by an increased dose twice daily for 12 weeks. Patient questionnaires using the visual analog scale revealed that pain severity decreased significantly in all patients during the treatment period. ${ }^{1{ }^{12}}$ ET- 1 was investigated as a potential marker for patients admitted to the emergency room for a sickle cell pain crisis and in patients with complex regional pain syndrome. ${ }^{143,144}$

At this time, the only licensed ET receptor antagonist medications available in the United States and Europe are bosentan, a dual $\mathrm{ET}_{\mathrm{A}} / \mathrm{ET}_{\mathrm{B}}$ receptor antagonist, and ambrisen$\tan$, a selective $\mathrm{ET}_{\mathrm{A}}$ receptor antagonist, for the treatment of pulmonary hypertension. ${ }^{145}$ The $\mathrm{ET}_{\mathrm{A}}$ receptor antagonists or combined $\mathrm{ET}_{\mathrm{A}} / \mathrm{ET}_{\mathrm{B}}$ receptor antagonists are currently in clinical trials for the treatment of diseases, including prostate, kidney, ovarian, fallopian, and peritoneal cancer, as well as diabetic neuropathy, diastolic heart failure, pulmonary arterial hypertension, pulmonary fibrosis, scleroderma, and subarachnoid hemorrhage. ${ }^{145}$ Many of the clinical trials are not aimed at pain relief but are targeting other actions of ET-1 in other systems. However, to gain the maximum benefit from these trials, the pain-producing (or pain-relieving) effects of ET-1 need to be better understood and evaluated. Pain reduction has already been reported in trials of bone and prostate cancer pain. ${ }^{4}$

Therefore, it is imperative that the current trials index changes in pain to elucidate all the possible benefits of endothelin receptor antagonists. This review of the literature on ET-1 beckons to clinical researchers to include a pain analysis within the ongoing studies. Possible painrelieving adverse effects may be completely overlooked without the needed attention from clinical studies. Significant pain relief may be an additional benefit in patients taking endothelin receptor antagonists for a variety of pathologies.

\section{Acknowledgments}

This work was funded by National Institutes of Health Grants R01 DA023593 and NS26363; a South Carolina Post-Baccalaureate Research Education Programs for Minorities, funded by grants R25 GM066526 and R25 GM076277 from the National Institutes of Health; and the Alfred P Sloan Foundation.

\section{Disclosure}

The authors report no conflicts of interest in this work.

\section{References}

1. Yanagisawa M, Kurihara H, Kimura S, Goto K, Masaki T. A novel peptide vasoconstrictor, endothelin, is produced by vascular endothelium and modulates smooth muscle $\mathrm{Ca} 2+$ channels. J Hypertens Suppl. 1988;6(4):S188-S191.

2. Rubanyi GM, Polokoff MA. Endothelins: molecular biology, biochemistry, pharmacology, physiology, and pathophysiology. Pharmacol Rev. 1994;46(3):325-415.

3. Giannessi D, Del Ry S, Vitale RL. The role of endothelins and their receptors in heart failure. Pharmacol Res. 2001;43(2):111-126.

4. Lalich M, McNeel DG, Wilding G, Liu G. Endothelin receptor antagonists in cancer therapy. Cancer Invest. 2007;25(8):785-794.

5. Dahlöf B, Gustafsson D, Hedner T, Jern S, Hansson L. Regional haemodynamic effects of endothelin-1 in rat and man: unexpected adverse reaction. J Hypertens. 1990;8(9):811-817.

6. Nelson JB, Hedican SP, George DJ, et al. Identification of endothelin-1 in the pathophysiology of metastatic adenocarcinoma of the prostate. Nat Med. 1995;1(9):944-949.

7. Lerman A, Edwards BS, Hallett JW, Heublein DM, Sandberg SM, Burnett JC Jr. Circulating and tissue endothelin immunoreactivity in advanced atherosclerosis. N Engl J Med. 1991;325(14):997-1001.

8. Suzuki T, Kumazaki T, Mitsui Y. Endothelin-1 is produced and secreted by neonatal rat cardiac myocytes in vitro. Biochem Biophys Res Commun. 1993;191(3):823-830.

9. Harada M, Itoh H, Nakagawa O, et al. Significance of ventricular myocytes and nonmyocytes interaction during cardiocyte hypertrophy: evidence for endothelin-1 as a paracrine hypertrophic factor from cardiac nonmyocytes. Circulation. 1997;96(10):3737-3744.

10. Hans G, Deseure K, Adriaensen H. Endothelin-1-induced pain and hyperalgesia: a review of pathophysiology, clinical manifestations and future therapeutic options. Neuropeptides. 2008;42(2):119-132.

11. Hasue F, Kuwaki T, Kisanuki YY, et al. Increased sensitivity to acute and persistent pain in neuron-specific endothelin-1 knockout mice. Neuroscience. 2005;130(2):349-358.

12. Liu Y, Yamada H, Ochi J. Immunocytochemical studies on endothelin in mast cells and macrophages in the rat gastrointestinal tract. Histochem Cell Biol. 1998;109(4):301-307.

13. Ehrenreich H, Anderson RW, Fox CH, et al. Endothelins, peptides with potent vasoactive properties, are produced by human macrophages. J Exp Med. 1990;172(6):1741-1748.

14. Carducci MA, Jimeno A. Targeting bone metastasis in prostate cancer with endothelin receptor antagonists. Clinical Cancer Research: An Official Journal of the American Association for Cancer Research. October 15, 2006;12(20 Pt 2):6296s-6300s.

15. Ahn GY, Butt KI, Jindo T, Yaguchi H, Tsuboi R, Ogawa H. The expression of endothelin-1 and its binding sites in mouse skin increased after ultraviolet B irradiation or local injection of tumor necrosis factor alpha. J Dermatol. 1998;25(2):78-84.

16. Kopetz ES, Nelson JB, Carducci MA. Endothelin-1 as a target for therapeutic intervention in prostate cancer. Invest New Drugs. 2002;20(2):173-182.

17. Moreau P, d'Uscio LV, Shaw S, Takase H, Barton M, Lüscher TF. Angiotensin II increases tissue endothelin and induces vascular hypertrophy: reversal by ET(A)-receptor antagonist. Circulation. 1997;96(5):1593-1597.

18. Wagner OF, Christ G, Wojta J, et al. Polar secretion of endothelin-1 by cultured endothelial cells. J Biol Chem. 1992;267(23):16066-16068.

19. Rubin SA, Levin ER. Clinical review 53: The endocrinology of vasoactive peptides: synthesis to function. J Clin Endocrinol Metab. 1994;78(1):6-10.

20. Bremnes T, Paasche JD, Mehlum A, Sandberg C, Bremnes B, Attramadal H. Regulation and intracellular trafficking pathways of the endothelin receptors. J Biol Chem. 2000;275(23):17596-17604.

21. Burkhardt M, Barton M, Shaw SG. Receptor- and non-receptormediated clearance of big-endothelin and endothelin-1: differential effects of acute and chronic ETA receptor blockade. J Hypertens. 2000;18(3):273-279. 
22. Gohla A, Schultz G, Offermanns S. Role for $\mathrm{G}(12) / \mathrm{G}(13)$ in agonist-induced vascular smooth muscle cell contraction. Circ Res. 2000;87(3):221-227.

23. Masaki T. Endothelin in vascular biology. Ann N Y Acad Sci. 1994;714(1):101-108.

24. Nicol GDET. ET - phone the pain clinic. Trends Neurosci. 2004;27(4):177-180, discussion 180.

25. Arai H, Hori S, Aramori I, Ohkubo H, Nakanishi S. Cloning and expression of a cDNA encoding an endothelin receptor. Nature. 1990;348(6303):730-732.

26. Sakurai T, Yanagisawa M, Takuwa Y, et al. Cloning of a cDNA encoding a non-isopeptide-selective subtype of the endothelin receptor. Nature. 1990;348(6303):732-735.

27. Rashid AJ, O'Dowd BF, George SR. Minireview: Diversity and complexity of signaling through peptidergic $\mathrm{G}$ protein-coupled receptors. Endocrinology. 2004;145(6):2645-2652.

28. Zhou Z, Davar G, Strichartz G. Endothelin-1 (ET-1) selectively enhances the activation gating of slowly inactivating tetrodotoxinresistant sodium currents in rat sensory neurons: a mechanism for the pain-inducing actions of ET-1. J Neurosci. 2002;22(15): 6325-6330.

29. Masaki T, Miwa S, Sawamura T, Ninomiya H, Okamoto Y. Subcellular mechanisms of endothelin action in vascular system. Eur J Pharmacol. 1999;375(1-3):133-138.

30. Ghoneim MA, Yamamoto T, Hirose S, Nagasawa T, Hagiwara H. Endothelium localization of ETB receptor revealed by immunohistochemistry. J Cardiovasc Pharmacol. 1993;22(Suppl 8): S111-S112.

31. Shetty SS, Okada T, Webb RL, DelGrande D, Lappe RW. Functionally distinct endothelin B receptors in vascular endothelium and smooth muscle. Biochem Biophys Res Commun. 1993;191(2):459-464.

32. Sakurai-Yamashita Y, Yamashita K, Yoshida A, et al. Rat peritoneal macrophages express endothelin ET(B) but not endothelin ET(A) receptors. Eur J Pharmacol. 1997;338(2):199-203.

33. Pomonis JD, Rogers SD, Peters CM, Ghilardi JR, Mantyh PW. Expression and localization of endothelin receptors: implications for the involvement of peripheral glia in nociception. J Neurosci. 2001;21(3): 999-1006.

34. Chichorro JG, Fiuza CR, Bressan E, Claudino RF, Leite DF, Rae GA. Endothelins as pronociceptive mediators of the rat trigeminal system: role of ETA and ETB receptors. Brain Res. 2010;1345:73-83.

35. Berti-Mattera LN, Gariepy CE, Burke RM, Hall AK. Reduced expression of endothelin $\mathrm{B}$ receptors and mechanical hyperalgesia in experimental chronic diabetes. Exp Neurol. 2006;201(2):399-406.

36. Plant TD, Zöllner C, Kepura F, et al. Endothelin potentiates TRPV1 via ETA receptor-mediated activation of protein kinase C. Mol Pain. 2007;3(1):35

37. Giaid A, Gibson SJ, Ibrahim BN, et al. Endothelin-1, an endotheliumderived peptide, is expressed in neurons of the human spinal cord and dorsal root ganglia. Proc Natl Acad Sci U S A. 1989;86(19): 7634-7638.

38. Feng B, Strichartz G. Endothelin-1 raises excitability and reduces potassium currents in sensory neurons. Brain Res Bull. 2009;79(6): 345-350.

39. Houck CS, Khodorova A, Reale AM, Strichartz GR, Davar G. Sensory fibers resistant to the actions of tetrodotoxin mediate nocifensive responses to local administration of endothelin-1 in rats. Pain. 2004;110(3):719-726.

40. Cardenas LM, Cardenas CG, Scroggs RS. 5HT increases excitability of nociceptor-like rat dorsal root ganglion neurons via cAMP-coupled TTX-resistant $\mathrm{Na}(+)$ channels. J Neurophysiol. 2001;86(1): 241-248.

41. Lee ME, de la Monte SM, Ng SC, Bloch KD, Quertermous T. Expression of the potent vasoconstrictor endothelin in the human central nervous system. J Clin Invest. 1990;86(1):141-147.

42. Giaid A, Gibson SJ, Herrero MT, et al. Topographical localisation of endothelin mRNA and peptide immunoreactivity in neurones of the human brain. Histochemistry. 1991;95(3):303-314.
43. Yoshizawa T, Kimura S, Kanazawa I, Uchiyama Y, Yanagisawa M, Masaki T. Endothelin localizes in the dorsal horn and acts on the spinal neurones: possible involvement of dihydropyridine-sensitive calcium channels and substance P release. Neurosci Lett. 1989;102(2-3): 179-184.

44. Kurokawa K, Yamada H, Ochi J. Topographical distribution of neurons containing endothelin type A receptor in the rat brain. J Comp Neurol. 1997;389(2):348-360.

45. Yamada H, Kurokawa K. Histochemical studies on endothelin and the endothelin-A receptor in the hypothalamus. J Cardiovasc Pharmacol. 1998;31(Suppl 1):S215-S218.

46. Ferreira SH, Romitelli M, de Nucci G. Endothelin-1 participation in overt and inflammatory pain. J Cardiovasc Pharmacol. 1989;13(Suppl 5): S220-S222.

47. Raffa RB, Jacoby HI. Endothelin-1, -2 and -3 directly and bigendothelin-1 indirectly elicit an abdominal constriction response in mice. Life Sci. 1991;48(17):PL85-PL90.

48. Raffa RB, Schupsky JJ, Martinez RP, Jacoby HI. Endothelin-1-induced nociception. Life Sci. 1991;49(11):PL61-PL65.

49. Hans G, Deseure K, Robert D, De Hert S. Neurosensory changes in a human model of endothelin-1 induced pain: a behavioral study. Neurosci Lett. 2007;418(2):117-121.

50. Gokin AP, Fareed MU, Pan HL, Hans G, Strichartz GR, Davar G. Local injection of endothelin-1 produces pain-like behavior and excitation of nociceptors in rats. $J$ Neurosci. 2001;21(14):5358-5366.

51. Namer B, Hilliges M, Orstavik K, et al. Endothelin-1 activates and sensitizes human C-nociceptors. Pain. 2008;137(1):41-49.

52. Piovezan AP, D’Orléans-Juste P, Tonussi CR, Rae GA. Endothelins potentiate formalin-induced nociception and paw edema in mice. Can J Physiol Pharmacol. 1997;75(6):596-600.

53. D’Amico M, Di Filippo C, Rossi F. Selective and non-selective ET antagonists reveal an ET(A)/ET(B) receptor mediated ET-1-induced antinociceptive effect in PAG area of mice. Life Sci. 1997;61(25): PL 397-PL 401

54. Schmelz M, Schmidt R, Weidner C, Hilliges M, Torebjork HE, Handwerker HO. Chemical response pattern of different classes of C-nociceptors to pruritogens and algogens. J Neurophysiol. 2003;89(5): 2441-2448.

55. Davar G, Hans G, Fareed MU, Sinnott C, Strichartz G. Behavioral signs of acute pain produced by application of endothelin-1 to rat sciatic nerve. Neuroreport. 1998;9(10):2279-2283.

56. Khodorova A, Strichartz GR. Contralateral paw sensitization following injection of endothelin-1: effects of local anesthetics differentiate peripheral and central processes. Neuroscience. 2010;165(2): 553-560.

57. Raffa RB, Schupsky JJ, Jacoby HI. Endothelin-induced nociception in mice: mediation by ETA and ETB receptors. J Pharmacol Exp Ther. 1996;276(2):647-651.

58. Piovezan AP, D’Orléans-Juste P, Souza GE, Rae GA. Endothelin-1induced ET(A) receptor-mediated nociception, hyperalgesia and oedema in the mouse hind-paw: modulation by simultaneous ET(B) receptor activation. Br J Pharmacol. 2000;129(5):961-968.

59. Khodorova A, Fareed MU, Gokin A, Strichartz GR, Davar G. Local injection of a selective endothelin-B receptor agonist inhibits endothelin-1-induced pain-like behavior and excitation of nociceptors in a naloxone-sensitive manner. J Neurosci. 2002;22(17): 7788-7796.

60. Menéndez L, Lastra A, Hidalgo A, Baamonde A. Nociceptive reaction and thermal hyperalgesia induced by local ET-1 in mice: a behavioral and Fos study. Naunyn Schmiedebergs Arch Pharmacol. 2003;367(1):28-34.

61. McKelvy AD, Mark TR, Sweitzer SM. Age- and sex-specific nociceptive response to endothelin-1. J Pain. 2007;8(8):657-666.

62. Shrestha S, Gracias NG, Mujenda F, Khodorova A, Vasko MR, Strichartz GR. Local antinociception induced by endothelin-1 in the hairy skin of the rat's back. J Pain. 2009;10(7):702-714.

63. Gomes LO, Hara DB, Rae GA. Endothelin-1 induces itch and pain in the mouse cheek model. Life Sci Mar. 2012;91(13-14):628-633. 
64. Khodorova A, Navarro B, Jouaville LS, et al. Endothelin-B receptor activation triggers an endogenous analgesic cascade at sites of peripheral injury. Nat Med. 2003;9(8):1055-1061.

65. da Cunha JM, Rae GA, Ferreira SH, Cunha FQ. Endothelins induce ETB receptor-mediated mechanical hypernociception in rat hindpaw: roles of cAMP and protein kinase C. Eur J Pharmacol. 2004;501(1-3): 87-94.

66. Motta EM, Calixto JB, Rae GA. Mechanical hyperalgesia induced by endothelin-1 in rats is mediated via phospholipase $\mathrm{C}$, protein kinase $\mathrm{C}$, and MAP kinases. Exp Biol Med (Maywood). 2006;231(6):1141-1145.

67. Baamonde A, Lastra A, Villazón M, Bordallo J, Hidalgo A, Menéndez L. Involvement of endogenous endothelins in thermal and mechanical inflammatory hyperalgesia in mice. Naunyn Schmiedebergs Arch Pharmacol. 2004;369(2):245-251.

68. Verri WA Jr, Schivo IR, Cunha TM, Liew FY, Ferreira SH, Cunha FQ. Interleukin-18 induces mechanical hypernociception in rats via endothelin acting on ETB receptors in a morphine-sensitive manner. J Pharmacol Exp Ther. 2004;310(2):710-717.

69. Khodorova A, Richter J, Vasko MR, Strichartz G. Early and late contributions of glutamate and CGRP to mechanical sensitization by endothelin-1. J Pain. 2009;10(7):740-749.

70. Kawamata T, Ji W, Yamamoto J, Niiyama Y, Furuse S, Namiki A. Contribution of transient receptor potential vanilloid subfamily 1 to endothelin-1-induced thermal hyperalgesia. Neuroscience. 2008;154(3):1067-1076.

71. Motta EM, Chichorro JG, D’Orléans-Juste P, Rae GA. Roles of endothelin ETA and ETB receptors in nociception and chemical, thermal and mechanical hyperalgesia induced by endothelin-1 in the rat hindpaw. Peptides. 2009;30(5):918-925.

72. Stösser S, Agarwal N, Tappe-Theodor A, Yanagisawa M, Kuner R. Dissecting the functional significance of endothelin A receptors in peripheral nociceptors in vivo via conditional gene deletion. Pain. 2010;148(2):206-214.

73. Plant TD, Zöllner C, Mousa SA, Oksche A. Endothelin-1 potentiates capsaicin-induced TRPV1 currents via the endothelin A receptor. Exp Biol Med (Maywood). 2006;231(6):1161-1164.

74. Yamamoto H, Kawamata T, Ninomiya T, Omote K, Namiki A. Endothelin-1 enhances capsaicin-evoked intracellular $\mathrm{Ca} 2+$ response via activation of endothelin a receptor in a protein kinase Cepsilondependent manner in dorsal root ganglion neurons. Neuroscience. 2006;137(3):949-960.

75. Piovezan AP, D’Orléans-Juste P, Tonussi CR, Rae GA. Effects of endothelin-1 on capsaicin-induced nociception in mice. Eur J Pharmacol. 1998;351(1):15-22.

76. Smith T, Beasley S, Smith S, Mark I, Sweitzer SM. Endothelin-1induced priming to capsaicin in young animals. Neurosci Lett. 2014;567:15-18.

77. Mujenda FH, Duarte AM, Reilly EK, Strichartz GR. Cutaneous endothelin-A receptors elevate post-incisional pain. Pain. 2007; 133(1-3):161-173.

78. Kamei J, Hitosugi H, Kawashima N, Misawa M, Kasuya Y. Antinociceptive effects of intrathecally administered endothelin-1 in mice. Neurosci Lett. 1993;153(1):69-72.

79. Yamamoto T, Shimoyama N, Asano H, Mizuguchi T. Analysis of the role of endothelin-A and endothelin-B receptors on nociceptive information transmission in the spinal cord with FR139317, an endothelin-A receptor antagonist, and sarafotoxin $\mathrm{S} 6 \mathrm{c}$, an endothelin-B receptor agonist. $J$ Pharmacol Exp Ther. 1994;271(1):156-163.

80. Hung VK, Chen SM, Tai LW, Chen AY, Chung SK, Cheung CW. Overexpression of endothelin-1 in astrocytes, but not endothelial cells, ameliorates inflammatory pain response after formalin injection. Life Sci. 2012;91(13-14):618-622.

81. D’Amico M, Berrino L, Maione S, Filippelli A, de Novellis V, Rossi F. Endothelin-1 in periaqueductal gray area of mice induces analgesia via glutamatergic receptors. Pain. 1996;65(2-3):205-209.

82. Hasue F, Kuwaki T, Yamada H, Fukuda Y, Shimoyama M. Inhibitory actions of endothelin-1 on pain processing. J Cardiovasc Pharmacol. 2004;44(Supp1 1):S318-S320.
83. Ergul A, Shoemaker K, Puett D, Tackett RL. Gender differences in the expression of endothelin receptors in human saphenous veins in vitro. J Pharmacol Exp Ther. 1998;285(2):511-517.

84. Yoshibayashi M, Nishioka K, Nakao K, et al. Plasma endothelin levels in healthy children: high values in early infancy. $J$ Cardiovasc Pharmacol. 1991;17(Supp1 7):S404-S405.

85. Giannessi D, Del Ry S, Andreassi MG, et al. High density of endothelin binding sites in the hearts of infants and children. Life Sci. 1999;64(8):697-705.

86. Joseph EK, Levine JD. Sexual dimorphism in endothelin-1 induced mechanical hyperalgesia in the rat. Exp Neurol. 2012;233(1): 505-512.

87. McKelvy AD, Sweitzer SM. Endothelin-1 exposure on postnatal day 7 alters expression of the endothelin B receptor and behavioral sensitivity to endothelin-1 on postnatal day 11. Neurosci Lett. 2009;451(1):89-93.

88. Cui P, Tani K, Kitamura H, et al. A novel bioactive 31-amino acid endothelin-1 is a potent chemotactic peptide for human neutrophils and monocytes. J Leukoc Biol. 2001;70(2):306-312.

89. Miyasaka N, Hirata Y, Ando K, et al. Increased production of endothelin-1 in patients with inflammatory arthritides. Arthritis Rheum. 1992;35(4):397-400

90. Khodorova A, Zou S, Ren K, Dubner R, Davar G, Strichartz G. Dual Roles for Endothelin-B Receptors in Modulating AdjuvantInduced Inflammatory Hyperalgesia in Rats. Open Pain J. 2009;2(1):30-40.

91. De-Melo JD, Tonussi CR, D’Orléans-Juste P, Rae GA. Articular nociception induced by endothelin-1, carrageenan and LPS in naive and previously inflamed knee-joints in the rat: inhibition by endothelin receptor antagonists. Pain. 1998;77(3):261-269.

92. De-Melo JD, Tonussi CR, D'Orléans-Juste P, Rae GA. Effects of endothelin-1 on inflammatory incapacitation of the rat knee joint. J Cardiovasc Pharmacol. 1998;31(Suppl 1):S518-S520.

93. Imhof AK, Glück L, Gajda M, Bräuer R, Schaible HG, Schulz S. Potent anti-inflammatory and antinociceptive activity of the endothelin receptor antagonist bosentan in monoarthritic mice. Arthritis Res Ther. 2011;13(3):R97.

94. Piovezan AP, D’Orléans-Juste P, Frighetto M, Souza GE, Henriques MG, Rae GA. Endothelins contribute towards nociception induced by antigen in ovalbumin-sensitised mice. Br J Pharmacol. 2004;141(4):755-763.

95. Pirtskhalaishvili G, Nelson JB. Endothelium-derived factors as paracrine mediators of prostate cancer progression. Prostate. 2000;44(1): 77-87.

96. Quang PN, Schmidt BL. Peripheral endothelin B receptor agonist-induced antinociception involves endogenous opioids in mice. Pain. 2010;149(2):254-262.

97. Davar G. Endothelin-1 and metastatic cancer pain. Pain Med 2001;2(1):24-27.

98. Yuyama H, Koakutsu A, Fujiyasu N, et al. Inhibitory effects of a selective endothelin-A receptor antagonist YM598 on endothelin-1induced potentiation of nociception in formalin-induced and prostate cancer-induced pain models in mice. J Cardiovasc Pharmacol. 2004; 44(Suppl 1):S479-S482.

99. Hamamoto DT, Khasabov SG, Cain DM, Simone DA. Tumor-evoked sensitization of C nociceptors: a role for endothelin. J Neurophysiol. 2008;100(4):2300-2311.

100. Pickering V, Jay Gupta R, Quang P, Jordan RC, Schmidt BL. Effect of peripheral endothelin-1 concentration on carcinoma-induced pain in mice. Eur J Pain. 2008;12(3):293-300.

101. Wacnik PW, Eikmeier LJ, Ruggles TR, et al. Functional interactions between tumor and peripheral nerve: morphology, algogen identification, and behavioral characterization of a new murine model of cancer pain. J Neurosci. 2001;21(23):9355-9366.

102. Peters CM, Lindsay TH, Pomonis JD, et al. Endothelin and the tumorigenic component of bone cancer pain. Neuroscience. 2004;126(4): 1043-1052. 
103. Schmidt BL, Pickering V, Liu S, et al. Peripheral endothelin A receptor antagonism attenuates carcinoma-induced pain. Eur J Pain. 2007;11(4):406-414.

104. Fujita M, Andoh T, Saiki I, Kuraishi Y. Involvement of endothelin and ET(A) endothelin receptor in mechanical allodynia in mice given orthotopic melanoma inoculation. J Pharmacol Sci. 2008;106(2): 257-263.

105. Baamonde A, Lastra A, Fresno MF, et al. Implantation of tumoral XC cells induces chronic, endothelin-dependent, thermal hyperalgesia in mice. Cell Mol Neurobiol. 2004;24(2):269-281.

106. Tada H, Muramatsu I, Nakai T, Kigoshi S, Miyabo S. Effects of chronic diabetes on the responsiveness to endothelin-1 and other agents of rat atria and thoracic aorta. Gen Pharmacol. 1994;25(6):1221-1228.

107. Jarvis MF, Wessale JL, Zhu CZ, et al. ABT-627, an endothelin ET(A) receptor-selective antagonist, attenuates tactile allodynia in a diabetic rat model of neuropathic pain. Eur J Pharmacol. 2000;388(1): 29-35.

108. Kamei J, Hitosugi H, Kawashima N, Misawa M, Kasuya Y. Effects of diabetes on the antinociceptive effects of intrathecally administered endothelin-1. Res Commun Chem Pathol Pharmacol. 1993;79(2): 209-217.

109. Chichorro JG, Zampronio AR, Rae GA. Endothelin ET(B) receptor antagonist reduces mechanical allodynia in rats with trigeminal neuropathic pain. Exp Biol Med (Maywood). 2006;231(6):1136-1140.

110. Chichorro JG, Zampronio AR, Souza GE, Rae GA. Orofacial cold hyperalgesia due to infraorbital nerve constriction injury in rats: reversal by endothelin receptor antagonists but not non-steroidal antiinflammatory drugs. Pain. 2006;123(1-2):64-74.

111. Millecamps M, Laferrière A, Ragavendran JV, Stone LS, Coderre TJ. Role of peripheral endothelin receptors in an animal model of complex regional pain syndrome type 1 (CRPS-I). Pain. 2010;151(1):174-183.

112. Klass M, Hord A, Wilcox M, Denson D, Csete M. A role for endothelin in neuropathic pain after chronic constriction injury of the sciatic nerve. Anesth Analg. 2005;101(6):1757-1762.

113. Werner MF, Trevisani M, Campi B, André E, Geppetti P, Rae GA. Contribution of peripheral endothelin ETA and ETB receptors in neuropathic pain induced by spinal nerve ligation in rats. Eur J Pain. 2010;14(9):911-917.

114. Raffa RB, Schupsky JJ, Lee DK, Jacoby HI. Characterization of endothelin-induced nociception in mice: evidence for a mechanistically distinct analgesic model. J Pharmacol Exp Ther. 1996;278(1):1-7.

115. Griswold DE, Douglas SA, Martin LD, et al. Endothelin B receptor modulates inflammatory pain and cutaneous inflammation. Mol Pharmacol. 1999;56(4):807-812.

116. Zagorodnyuk VP, Kyloh M, Nicholas S, et al. Loss of visceral pain following colorectal distension in an endothelin-3 deficient mouse model of Hirschsprung's disease. J Physiol. 2011;589(Pt 7):1691-1706.

117. Kanazawa S, Tsunoda T, Onuma E, Majima T, Kagiyama M, Kikuchi K. VEGF, basic-FGF, and TGF-beta in Crohn's disease and ulcerative colitis: a novel mechanism of chronic intestinal inflammation. Am J Gastroenterol. 2001;96(3):822-828.

118. Murch SH, Braegger CP, Sessa WC, MacDonald TT. High endothelin-1 immunoreactivity in Crohn's disease and ulcerative colitis. Lancet. 1992;339(8790):381-385.

119. Letizia C, Boirivant M, De Toma G, et al. Plasma levels of endothelin-1 in patients with Crohn's disease and ulcerative colitis. Ital J Gastroenterol Hepatol. 1998;30(3):266-269.

120. Shiu YT, McIntire LV, Udden MM. Sickle erythrocytes increase prostacyclin and endothelin-1 production by cultured human endothelial cells under flow conditions. Eur J Haematol. 2002;68(3):163-169.

121. Phelan M, Perrine SP, Brauer M, Faller DV. Sickle erythrocytes, after sickling, regulate the expression of the endothelin-1 gene and protein in human endothelial cells in culture. $J$ Clin Invest. 1995;96(2):1145-1151.
122. Hammerman SI, Kourembanas S, Conca TJ, Tucci M, Brauer M, Farber HW. Endothelin-1 production during the acute chest syndrome in sickle cell disease. Am J Respir Crit Care Med. 1997;156(1): 280-285.

123. Tharaux PL, Hagège I, Placier S, et al. Urinary endothelin-1 as a marker of renal damage in sickle cell disease. Nephrol Dial Transplant. 2005;20(11):2408-2413.

124. Graido-Gonzalez E, Doherty JC, Bergreen EW, Organ G, Telfer M, McMillen MA. Plasma endothelin-1, cytokine, and prostaglandin E2 levels in sickle cell disease and acute vaso-occlusive sickle crisis. Blood. 1998;92(7):2551-2555.

125. Ergul S, Brunson CY, Hutchinson J, et al. Vasoactive factors in sickle cell disease: in vitro evidence for endothelin-1-mediated vasoconstriction. Am J Hematol. 2004;76(3):245-251.

126. Rybicki AC, Benjamin LJ. Increased levels of endothelin-1 in plasma of sickle cell anemia patients. Blood. 1998;92(7):2594-2596.

127. Brun M, Bourdoulous S, Couraud PO, Elion J, Krishnamoorthy R, Lapoumeroulie C. Hydroxyurea downregulates endothelin-1 gene expression and upregulates ICAM-1 gene expression in cultured human endothelial cells. Pharmacogenomics J. 2003;3(4): 215-226.

128. Odièvre MH, Brun M, Krishnamoorthy R, Lapouméroulie C, Elion J. Sodium phenyl butyrate downregulates endothelin-1 expression in cultured human endothelial cells: relevance to sickle-cell disease. Am J Hematol. 2007;82(5):357-362.

129. Lapouméroulie C, Benkerrou M, Odièvre MH, Ducrocq R, Brun M, Elion J. Decreased plasma endothelin-1 levels in children with sickle cell disease treated with hydroxyurea. Haematologica. 2005;90(3):401-403.

130. De Franceschi L, Platt OS, Malpeli G, et al. Protective effects of phosphodiesterase-4 (PDE-4) inhibition in the early phase of pulmonary arterial hypertension in transgenic sickle cell mice. FASEB J. 2008;22(6):1849-1860.

131. Sabaa N, de Franceschi L, Bonnin P, et al. Endothelin receptor antagonism prevents hypoxia-induced mortality and morbidity in a mouse model of sickle-cell disease. J Clin Invest. 2008;118(5): 1924-1933.

132. Schlenz AM, McClellan CB, Mark TR, et al. Sensitization to acute procedural pain in pediatric sickle cell disease: modulation by painful vaso-occlusive episodes, age, and endothelin-1. J Pain. 2012;13(7):656-665.

133. Rivera A, Jarolim P, Brugnara C. Modulation of Gardos channel activity by cytokines in sickle erythrocytes. Blood. 2002;99(1):357-603.

134. Benza RL. Pulmonary hypertension associated with sickle cell disease: pathophysiology and rationale for treatment. Lung. 2008;186(4):247-254.

135. Rivera A. Reduced sickle erythrocyte dehydration in vivo by endothelin-1 receptor antagonists. Am J Physiol Cell Physiol. 2007;293(3):C960-C966.

136. Chaar V, Tarer V, Etienne-Julan M, Diara JP, Elion J, Romana M. ET-1 and ecNOS gene polymorphisms andsusceptibility to acute chest syndrome and painful vaso-occlusive crises in children with sickle cell anemia. Haematologica. 2006;91(9): 1277-1278.

137. Gladwin MT, Crawford JH, Patel RP. The biochemistry of nitric oxide, nitrite, and hemoglobin: role in blood flow regulation. Free Radic Biol Med. 2004;36(6):707-717.

138. Morris CR, Gladwin MT, Kato GJ. Nitric oxide and arginine dysregulation: a novel pathway to pulmonary hypertension in hemolytic disorders. Curr Mol Med. 2008;8(7):620-632.

139. Wood KC, Hsu LL, Gladwin MT. Sickle cell disease vasculopathy: a state of nitric oxide resistance. Free Radic Biol Med. 2008;44(8): 1506-1528.

140. Bhalla S, Matwyshyn G, Gulati A. Morphine tolerance does not develop in mice treated with endothelin-A receptor antagonists. Brain Res. 2005;1064(1-2):126-135. 
141. Matwyshyn GA, Bhalla S, Gulati A. Endothelin ETA receptor blockade potentiates morphine analgesia but does not affect gastrointestinal transit in mice. Eur J Pharmacol. 2006;543(1-3):48-53.

142. Selenko-Gebauer N, Duschek N, Minimair G, Stingl G, Karlhofer F. Successful treatment of patients with severe secondary Raynaud's phenomenon with the endothelin receptor antagonist bosentan. Rheumatology (Oxford). 2006;45(Suppl 3):iii45-iii48.

143. Naprawa JT, Bonsu BK, Goodman DG, Ranalli MA. Serum biomarkers for identifying acute chest syndrome among patients who have sickle cell disease and present to the emergency department. Pediatrics. 2005;116(3):e420-e425.

144. Munts AG, Zijlstra FJ, Nibbering PH, et al. Analysis of cerebrospinal fluid inflammatory mediators in chronic complex regional pain syndrome related dystonia. Clin J Pain. 2008;24(1):30-34.
145. Dhaun N, Webb DJ. Endothelin-receptor antagonism: the future is bright. Lancet. 2008;371(9630):2061-2062.

146. Griswold DE, Douglas SA, Martin LD, et al. Targeted disruption of the endothelin-B-receptor gene attenuates inflammatory nociception and cutaneous inflammation in mice. J Cardiovasc Pharmacol. 2000;36(5) (Suppl 1):S78-S81.

147. Cain DM, Wacnik PW, Eikmeier L, Beitz A, Wilcox GL, Simone DA. Functional interactions between tumor and peripheral nerve in a model of cancer pain in the mouse. Pain Med. 2001;2(1):15-23.
Journal of Pain Research

\section{Publish your work in this journal}

The Journal of Pain Research is an international, peer-reviewed, open access, online journal that welcomes laboratory and clinical findings in the fields of pain research and the prevention and management of pain. Original research, reviews, symposium reports, hypothesis formation and commentaries are all considered for publication.

\section{Dovepress}

The manuscript management system is completely online and includes a very quick and fair peer-review system, which is all easy to use. Visit http://www.dovepress.com/testimonials.php to read real quotes from published authors. 